\title{
Pemilihan Calon Penerima Bantuan Siswa Miskin Menggunakan Metode Analytical Hierarchy Process (AHP)
}

\author{
Selection of Candidates for Recipients Bantuan Siswa Miskin \\ Using Analytical Hierarchy Process (AHP) \\ Teuku Mufizar*1, Dede Syahrul Anwar ${ }^{2}$, Rustin Kania Dewi ${ }^{3}$ \\ 1,2,3 STMIK Tasikmalaya \\ e-mail: *1izargama@gmail.com ${ }^{2}$ derul@gmail.com, ${ }^{3}$ rustinkania@gmail.com
}

\begin{abstract}
Abstrak
Proses pemilihan calon penerima Bantuan Siswa Miskin (BSM) di SMPN 4 Ciamis masih banyak kelemahan diantaranya masih menggunakan proses manual dan penilaian yang bersifat subjektif. Untuk mengatasi hal tersebut maka dibangun sistem pendukung keputusan untuk menentukan penerima bantuan siswa miskin SMP Negeri 4 Ciamis menggunakan metode Analitical Hierarchy Process. Adapun kriteria yang ditetapkan oleh pihak sekolah diantaranya: Kepemilikan KPS (Kartu Perlindungan Sosial), Kepemilikan Orang Tua, Penghasilan Orang Tua, Tanggungan Orang Tua, Jarak Rumah, Kepribadian, Kehadiran, Nilai rapor semester, Prestasi Akademik, Prestasi Non Akademik, Pertimbanggan Lain. Dalam sistem pendukung keputusan ini didukung oleh suatu metode dalam pengambilan keputusan yaitu metode Analytical Hierarchy Process (AHP) yang dikonversikan kedalam bahasa pemrograman JAVA yang dapat menunjang dalam pengolahan data. Alat bantu pemodelan datanya menggunakan UML sedangkan teknik perancangan basisdata menggunakan Entity Relationship Diagram (ERD). Hasil akhir dari penelitian ini didapat bahwa sistem yang dibangun dapat membantu kerja Tim Penyeleksi BSM dalam melakukan proses penentuan penerima bantuan lebih tepat sasaran.
\end{abstract}

Kata Kunci — Sistem Pendukung Keputusan, Bantuan Siswa Miskin, AHP

\begin{abstract}
The process of selecting candidates for Bantuan Siswa Miskin (BSM) in SMPN 4 Ciamis still many weaknesses which are still using manual processes and assessments are subjective. To solve it is built decision support system to determine the recipient BSM of SMPN 4 Ciamis using Analytical Hierarchy Process. The criteria include: Owners KPS Card, Ownership Parent, Income Parents, Dependent Parent, Distance House, personality, presence, Value report semesters, Achievement, Achievement Non-Academic, and Additional considerations. In a decision support system is supported by a decision-making method is the method of Analytical Hierarchy Process (AHP), which is converted into JAVA programming language that can support in data processing. Data modeling tools using UML while the technique of database design using Entity Relationship Diagram (ERD). The final results of this study found that a system can help a team of Selectors BSM in conducting the process of determining the recipient target more appropriate.
\end{abstract}

Keywords — Decision Support System, Bantuan Siswa Miskin, AHP. 


\section{PENDAHULUAN}

SMP Negeri 4 Ciamis merupakan salah satu sekolah penerima Bantuan Siswa Miskin (BSM) dari Dinas Pendidikan dan Kebudayaan Kabupaten Ciamis. Pemberian BSM ini dilakukan untuk membantu siswa yang tidak mampu ataupun berprestasi selama menempuh studinya. Dalam menentukan siapa yang layak menerima BSM ini perlu dilakukan pengolahan data yang tepat agar diharapkan siswa yang benar-benar membutuhkan BSM ini bisa tercapai.

Pemilihan calon penerimaan BSM di SMP Negeri 4 Ciamis masih dicatat manual dan untuk pelaporannya menggunakan aplikasi pengola angka (spreadsheet) yang belum berbasis database, sehingga memungkinkan terjadinya redudansi dan inkonsistensi data. Selain itu, dalam penilaian dari setiap kriteria belum menggunakan suatu metode keputusan, sehingga penilaian antar calon penerima masih menggunakan prediksi atau perkiraan. Hal tersebut, dikhawatirkan dapat menimbulkan penilaian yang bersifat subjektif, dimana penilaian dilakukan berdasarkan kepentingan pribadi sehingga menimbulkan kurang tepatnya penyaluran beasiswa Bantuan Siswa Miskin (BSM). Oleh sebab itu diperlukan teknologi berupa aplikasi yang dapat membantu memberikan solusi untuk permasalahan tersebut. Dengan dibangunnya sebuah sistem pendukung keputusan yang terkomputerisasi, maka subjektifitas dalam pengambilan keputusan dapat dikurangi dan diganti dengan pelaksanaan seluruh kriteria-kriteria sehingga penerima beasiswa yang layak yang akan terpilih [1]. Pembuatan SPK ini diharapkan akan menyelesaikan permasalahan yang dihadapi dan sistem yang dibangun nantinya menggunakan kriteria-kriteria yang relevan sehingga hasil akhirnya siswa yang terpilih merupakan hasil penyeleksian dari siswa yang paling tepat untuk siswa SMP Negeri 4 Ciamis.

Adapun metode yang digunakan yaitu metode Analytic Hierarchy Process. AHP merupakan alat pengambilan keputusan dari beberapa kriteria yang merupakan nilai pendekatan Eigen untuk perbandingan berpasangan dan menyediakan metodologi untuk mengkalibrasi numerik untuk skala pengukuran kuantitatif serta sebagai pertunjukan kualitatif. Skala berkisar dari 1/9 untuk setidaknya dihargai daripada, untuk 1 untuk sama, dan 9 untuk benar-benar lebih penting daripada meliputi seluruh spektrum perbandingan [2].

Dalam pembangunan SPK ini, salah satu jurnal yang menjadi referensi yaitu penelitian yang dilakukan oleh Bagas Dista Ariyadi. Dalam jurnal tersebut, peneliti melakukan penelitian terhadap Sistem Pendukung Keputusan Seleksi Penerima Beasiswa pada SMA 1 Boja dengan Menggunakan Metode Analytical Hierarchy Process (AHP). Adapun kriteria penilaiannya terdiri dari 4 jenis kriteria, yaitu: prestasi akademik, prestasi non-akademik, penghasilan orangtua, kepribadian [3].

Jurnal kedua yang menjadi acuan yaitu penelitian yang dilakukan oleh Saelindri, Pratnya Satria. Penelitian ini mengenai Sistem Penduung Keputusan Untuk Menentukan Kelayakan Penerimaan Bantuan Siswa Miskin (BSM) Dengan Menggunakan Metode Topsis. Adapun kriteria yang dipakai yaitu memiliki tingkat kehadiran $75 \%$ di sekolah, memiliki kepribadian terpuji: rajin \& disiplin, tat aturan \& tata tertib, santun, tidak merokok/narkoba, orang tua siswa terdaftar sebagai siswa PKH, orang tua siswa penerima kartu perlindungan sosial, yatim dan/atau piatu, siswa terancam putus sekolah karena kesulitan biaya, pertimbangan lain (misalnya kelainan fisik, korban musibah berkepanjangan, anak korban PHK, atau indikator lainnya) [4].

Jurnal ketiga yang dijadikan acuan oleh peneliti yaitu penelitian yang dilakukan oleh Galih Eka Rinaldhi. Penelitian ini dilakukan untuk Penerapan metode Simple Additive Weighthing (SAW) untuk Sistem Pendukung Keputusan Penentuan Penerimaan Beasiswa Bantuan Siswa Miskin (BSM) pada SMA negeri 1 Subaah Kab.Batang. Kriteria yang digunakan adalah gaji orang tua, jumlah tanggungan, nilai rapor, kepribadian, prestasi [5].

Jurnal keempat yang dijadikan acuan oleh peneliti yaitu penelitian yang dilakukan oleh peneliti pada tahun 2015 [6]. Penelitian ini membangun Sistem Pendukung Keputusan Untuk Menyeleksi Calon Penerima Bantuan Siswa Miskin (BSM) di MTs Negeri Ciamis Menggunakan Metode Simple Additive Weighing (SAW). Kriteria yang digunakan adalah Jumlah Penghasilan Orang tua, Jumlah Tanggungan Orang tua, Nilai Raport, Kepribadian, Prestasi, Kaum Dhuafa, Banyaknya Absensi Siswa Yang Alfa, dan Mendapat bantuan Program Pemerintah. 
Dari referensi-referensi jurnal diatas, dapat terlihat adanya perbandingan dengan penelitian yang saat ini dilakukan. Penelitian saat ini memiliki perbedaan dengan penelitian [4,5,6] dari sisi metode yang dipakai, yaitu TOPSIS dan SAW. Sedangkan kalau dibandingkan dengan penelitian [3], walaupun ada kesamaan dari sisi penggunaan metode yaitu metode AHP, akan tetapi dalam penelitian ini peneliti melakukan pengembangan dari penelitian tersebut yaitu dengan menambahkan kriteria yang digunakan menjadi 11 kriteria yaitu Kepemilikan KPS (Kartu Perlindungan Sosial), Kepemilikan Orang Tua, Penghasilan Orang Tua, Tanggungan Orang Tua, Jarak Rumah, Kepribadian, Kehadiran, Nilai rapor semester, Prestasi Akademik, Prestasi Non Akademik, Pertimbanggan Lain. Penambahan kriteria ini didasarkan pada hasil wawancara dan persetujuan dari tempat penelitian yaitu dari pihak SMP Negeri 4 Ciamis.

\section{METODE PENELITIAN}

Alur penelitian dengan metode AHP dalam penerima bantuan siswa miskin di SMP Negeri 4 Ciamis bisa dilihat pada Gambar 1.

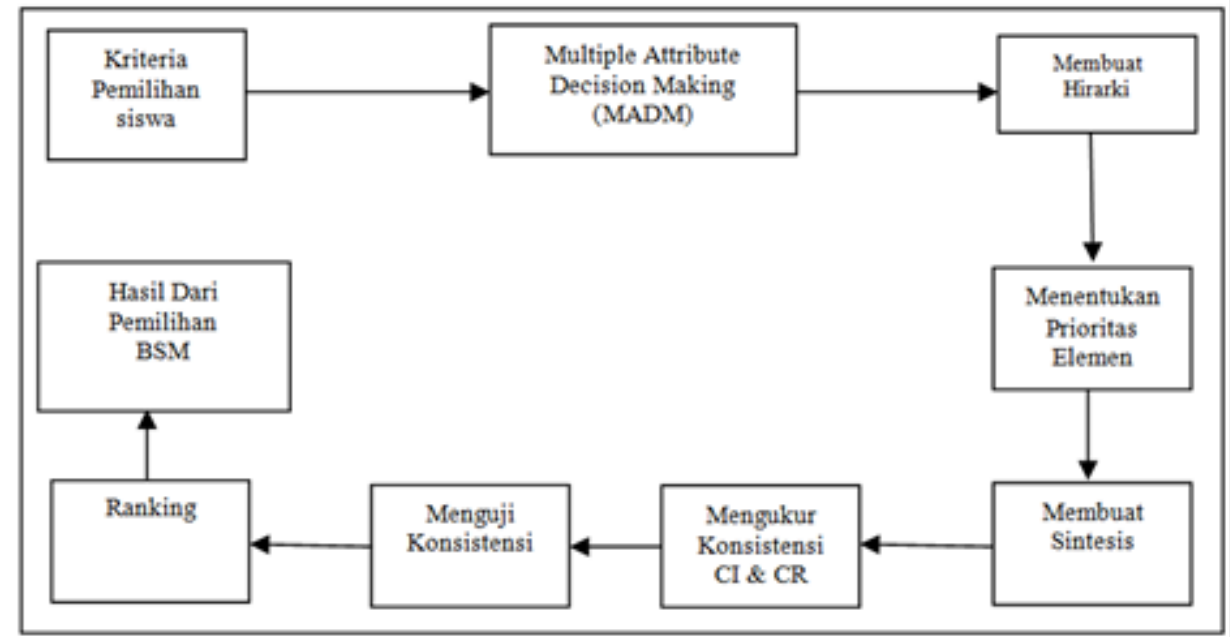

Gambar 1. Alur penelitian dengan metode AHP dalam pemilihan calon penerima BSM

Langkah-langkah dalam metode AHP secara umum untuk pemecahan suatu masalah adalah sebagai berikut: [7]

1. Mendefinisikan masalah dan menentukan solusi yang diinginkan, lalu menyusun hierarki dari permasalahan yang dihadapi.

2. Menentukan prioritas elemen

3. Sintesis

4. Mengukur Konsistensi

5. Hitung Consistency Index (CI)

6. Hitung Rasio Konsistensi/Consistency Ratio (CR)

7. Memeriksa konsistensi hierarki. 
Citec Journal, Vol. 4, No. 1, November 2016 - Januari 2017

\section{HASIL DAN PEMBAHASAN}

\subsection{Analisis Kebutuhan Metode AHP}

\subsubsection{Menentukan Kriteria}

Dalam metode AHP terdapat kriteria yang dibutuhkan untuk proses perhitungan. Dalam kasus ini terdapat 11 kriteria yang akan digunakan untuk proses pengambilan keputusan penerima bantuan siswa miskin di SMP Negeri 4 Ciamis. Kriteria-kriteria tersebut adalah:
1) Kepemilikan KPS (KKPS)
3) Penghasilan Orang Tua (POT)
5) Jarak Rumah (JR)
7) Kehadiran $(\mathrm{KH})$
9) Prestasi Akademik (PA)
11) Pertimbanggan Lain (PL)

2) Kepemilikan Orang Tua (KOT)

4) Tanggungan Orang Tua (TOA)

6) Kepribadian (KP)

8) Nilai rapor semester (NS)

10) Prestasi Non Akademik (PNA)

\subsubsection{Menyusun Hierarki Penerimaan bantuan Siswa Miskin (BSM)}

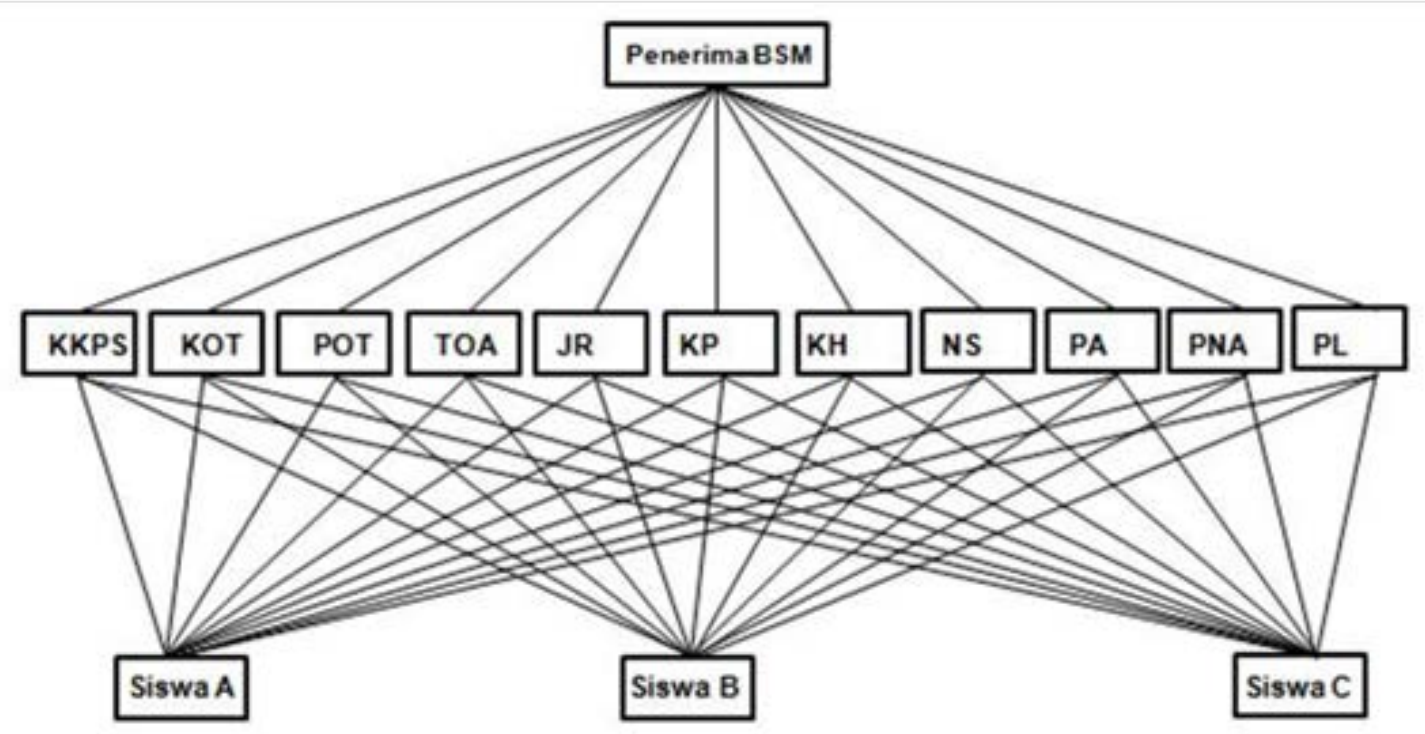

Gambar 2. Hierarki Penerima BSM

\subsubsection{Menentukan Matriks Perbandingan Berpasangan}

Pada tahap ini dilakukan penilaian perbandingan antara satu kriteria dengan kriteria yang lain. Angka 1 pada kolom KKPS dan nilai KOT merupakan hasil hitungan dari 1/nilai pada kolom nilai KOT. Angka-angka yang lain diperoleh dengan cara yang sama. Hasil penilaian bisa dilihat dalam Tabel 1. 
Tabel 1. Matriks Perbandingan Berpasangan

\begin{tabular}{|l|l|l|l|l|l|l|l|l|l|l|l|}
\hline Kriteria & KKPS & KOT & POT & TOA & JR & KP & KH & NS & PA & PNA & PL \\
\hline KKPS & 1 & 1 & 1 & 2 & 2 & 2 & 3 & 5 & 5 & 5 & 2 \\
\hline KOT & 1 & 1 & 1 & 2 & 2 & 2 & 3 & 5 & 5 & 5 & 2 \\
\hline POT & 1 & 1 & 1 & 1 & 2 & 2 & 3 & 3 & 3 & 3 & 2 \\
\hline TOA & 0.5 & 0.5 & 1 & 1 & 1 & 2 & 3 & 3 & 3 & 3 & 2 \\
\hline JR & 0.5 & 0.5 & 0.5 & 1 & 1 & 1 & 3 & 3 & 3 & 3 & 3 \\
\hline KP & 0.5 & 0.5 & 0.5 & 0.5 & 1 & 1 & 3 & 3 & 2 & 3 & 3 \\
\hline KH & 0.33 & 0.33 & 0.33 & 0.33 & 0.33 & 0.33 & 1 & 3 & 2 & 3 & 3 \\
\hline NS & 0.20 & 0.20 & 0.33 & 0.33 & 0.33 & 0.33 & 0.33 & 1 & 2 & 2 & 5 \\
\hline PA & 0.20 & 0.20 & 0.33 & 0.33 & 0.33 & 0.5 & 0.5 & 0.5 & 1 & 2 & 5 \\
\hline PNA & 0.20 & 0.20 & 0.33 & 0.33 & 0.33 & 0.33 & 0.33 & 0.5 & 0.5 & 1 & 5 \\
\hline PL & 0.5 & 0.5 & 0.5 & 0.5 & 0.33 & 0.33 & 0.33 & 0.2 & 0.2 & 0.2 & 1 \\
\hline Jumlah & $\mathbf{5 . 9 3}$ & $\mathbf{5 . 9 3}$ & $\mathbf{6 . 8 2}$ & $\mathbf{9 . 3 2}$ & $\mathbf{1 0 . 6 5}$ & $\mathbf{1 1 . 8 2}$ & $\mathbf{2 0 . 4 9}$ & $\mathbf{2 7 . 2 0}$ & $\mathbf{2 6 . 7 0}$ & $\mathbf{3 0 . 2 0}$ & $\mathbf{3 3 . 0 0}$ \\
\hline
\end{tabular}

\subsubsection{Membuat Matrik Nilai Kerja}

Matriks ini diperoleh dengan Rumus:

Nilai baris kolom baru = Nilai baris kolom lama $/$ jumlah masing-masing kolom lama .

Hasil perhitungan bisa dilihat pada tabel 2 .

Tabel 2. Matriks Nilai Kerja

\begin{tabular}{|l|l|l|l|l|l|l|l|l|l|l|l|l|l|}
\hline Kriteria & KKPS & KOT & POT & TOA & JR & KP & KH & NS & PA & PNA & PL & Jumlah & Prioritas \\
\hline KKPS & 0.17 & 0.17 & 0.15 & 0.21 & 0.19 & 0.17 & 0.15 & 0.18 & 0.19 & 0.17 & 0.06 & $\mathbf{1 . 8 0}$ & $\mathbf{0 . 1 6}$ \\
\hline KOT & 0.17 & 0.17 & 0.15 & 0.21 & 0.19 & 0.17 & 0.15 & 0.18 & 0.19 & 0.17 & 0.06 & $\mathbf{1 . 8 0}$ & $\mathbf{0 . 1 6}$ \\
\hline POT & 0.17 & 0.17 & 0.15 & 0.11 & 0.19 & 0.17 & 0.15 & 0.11 & 0.11 & 0.10 & 0.06 & $\mathbf{1 . 4 8}$ & $\mathbf{0 . 1 3}$ \\
\hline TOA & 0.08 & 0.08 & 0.15 & 0.11 & 0.09 & 0.17 & 0.15 & 0.11 & 0.11 & 0.10 & 0.06 & $\mathbf{1 . 2 1}$ & $\mathbf{0 . 1 1}$ \\
\hline JR & 0.08 & 0.08 & 0.07 & 0.11 & 0.09 & 0.08 & 0.15 & 0.11 & 0.11 & 0.10 & 0.09 & $\mathbf{1 . 0 9}$ & $\mathbf{0 . 1 0}$ \\
\hline KP & 0.08 & 0.08 & 0.07 & 0.05 & 0.09 & 0.08 & 0.15 & 0.11 & 0.07 & 0.10 & 0.09 & $\mathbf{1 . 0 0}$ & $\mathbf{0 . 0 9}$ \\
\hline KH & 0.06 & 0.06 & 0.05 & 0.04 & 0.03 & 0.03 & 0.05 & 0.11 & 0.07 & 0.10 & 0.09 & $\mathbf{0 . 6 8}$ & $\mathbf{0 . 0 6}$ \\
\hline NS & 0.03 & 0.03 & 0.05 & 0.04 & 0.03 & 0.03 & 0.02 & 0.04 & 0.07 & 0.07 & 0.15 & $\mathbf{0 . 5 6}$ & $\mathbf{0 . 0 5}$ \\
\hline PA & 0.03 & 0.03 & 0.05 & 0.04 & 0.03 & 0.04 & 0.02 & 0.02 & 0.04 & 0.07 & 0.15 & $\mathbf{0 . 5 2}$ & $\mathbf{0 . 0 5}$ \\
\hline PNA & 0.03 & 0.03 & 0.05 & 0.04 & 0.03 & 0.03 & 0.02 & 0.02 & 0.02 & 0.03 & 0.15 & $\mathbf{0 . 4 5}$ & $\mathbf{0 . 0 4}$ \\
\hline PL & 0.08 & 0.08 & 0.07 & 0.05 & 0.03 & 0.03 & 0.02 & 0.01 & 0.01 & 0.01 & 0.03 & $\mathbf{0 . 4 2}$ & $\mathbf{0 . 0 4}$ \\
\hline
\end{tabular}


Citec Journal, Vol. 4, No. 1, November 2016 - Januari 2017

Total nilai prioritas digunakan untuk mendapatkan bobot kriteria seperti pada Tabel 3 sehingga menjadi:

Table 3. Bobot Kriteria

\begin{tabular}{|l|l|}
\hline Kriteria & Bobot \\
\hline Kepemilikan KPS & 0.16 \\
\hline Kepemilikan Orang Tua & 0.16 \\
\hline Pengahasilan Orang Tua & 0.13 \\
\hline Tanggungan Orang Tua & 0.11 \\
\hline Jarak Rumah & 0.10 \\
\hline Kepribadian & 0.09 \\
\hline Kehadiran & 0.06 \\
\hline Nilai semester & 0.05 \\
\hline Prestasi Akademik & 0.05 \\
\hline Prestasi Non-Akademik & 0.04 \\
\hline Pertimbangan lain & 0.04 \\
\hline
\end{tabular}

\subsubsection{Membuat Matrik penjumlahan tiap Baris}

Matriks ini dibuat dengan mengkalikan nilai prioritas pada Tabel 3 dengan matriks perbandingan berpasangan (Tabel 1) hasil perhitungan bisa dilihat pada Tabel 4.

Tabel 4. Matriks Penjumlahan Tiap Baris

\begin{tabular}{|l|l|l|l|l|l|l|l|l|l|l|l|l|}
\hline Kriteria & KKPS & KOT & POT & TOA & JR & KP & KH & NS & PA & PNA & PL & jumlah \\
\hline KKPS & 0.16 & 0.16 & 0.13 & 0.22 & 0.20 & 0.18 & 0.19 & 0.25 & 0.24 & 0.20 & 0.08 & $\mathbf{2 . 0 2}$ \\
\hline KOT & 0.16 & 0.16 & 0.13 & 0.22 & 0.20 & 0.18 & 0.19 & 0.25 & 0.24 & 0.20 & 0.08 & $\mathbf{2 . 0 2}$ \\
\hline POT & 0.16 & 0.16 & 0.13 & 0.11 & 0.20 & 0.18 & 0.19 & 0.15 & 0.14 & 0.12 & 0.08 & $\mathbf{1 . 6 3}$ \\
\hline TOA & 0.08 & 0.08 & 0.13 & 0.11 & 0.10 & 0.18 & 0.19 & 0.15 & 0.14 & 0.12 & 0.08 & $\mathbf{1 . 3 7}$ \\
\hline JR & 0.08 & 0.08 & 0.07 & 0.11 & 0.10 & 0.09 & 0.19 & 0.15 & 0.14 & 0.12 & 0.12 & $\mathbf{1 . 2 5}$ \\
\hline KP & 0.08 & 0.08 & 0.07 & 0.06 & 0.10 & 0.09 & 0.19 & 0.15 & 0.09 & 0.12 & 0.12 & $\mathbf{1 . 1 5}$ \\
\hline KH & 0.05 & 0.05 & 0.04 & 0.04 & 0.03 & 0.03 & 0.06 & 0.15 & 0.09 & 0.00 & 0.12 & $\mathbf{0 . 6 8}$ \\
\hline NS & 0.03 & 0.03 & 0.04 & 0.04 & 0.03 & 0.03 & 0.02 & 0.05 & 0.09 & 0.08 & 0.20 & $\mathbf{0 . 6 6}$ \\
\hline PA & 0.03 & 0.03 & 0.04 & 0.04 & 0.03 & 0.05 & 0.03 & 0.03 & 0.05 & 0.08 & 0.20 & $\mathbf{0 . 6 1}$ \\
\hline PNA & 0.03 & 0.03 & 0.04 & 0.04 & 0.03 & 0.03 & 0.02 & 0.03 & 0.02 & 0.04 & 0.20 & $\mathbf{0 . 5 2}$ \\
\hline PL & 0.08 & 0.08 & 0.07 & 0.06 & 0.03 & 0.03 & 0.02 & 0.01 & 0.01 & 0.01 & 0.04 & $\mathbf{0 . 4 4}$ \\
\hline
\end{tabular}

\subsubsection{Membuat Rasio Konsistensi}

Perhitungan ini digunakan untuk memastikan bahwa nilai rasio konsistensi (CR) $<=0.1$. Jika ternyata nilai CR lebih dari 0.1, maka matriks perbandingan berpasangan harus diperbaiki. Untuk menghitung rasio konsistensi, dibuat tabel rasio konsistensi seperti terlihat pada Tabel 5: 
Tabel 5. Rasio Konsistensi

\begin{tabular}{|l|l|l|l|}
\hline Kriteria & jumlah & prioritas & hasil \\
\hline KKPS & 2.02 & 0.16 & 12.36 \\
\hline KOT & 2.02 & 0.16 & 12.36 \\
\hline POT & 1.63 & 0.13 & 12.16 \\
\hline TOA & 1.37 & 0.11 & 12.42 \\
\hline JR & 1.25 & 0.10 & 12.69 \\
\hline KP & 1.15 & 0.09 & 12.72 \\
\hline KH & 0.68 & 0.06 & 11.06 \\
\hline NS & 0.66 & 0.05 & 13.06 \\
\hline PA & 0.61 & 0.05 & 12.90 \\
\hline PNA & 0.52 & 0.04 & 12.83 \\
\hline PL & 0.44 & 0.04 & 11.39 \\
\hline Jumlah & & & $\mathbf{1 1 1 . 7 2}$ \\
\hline
\end{tabular}

Kolom jumlah per baris diperoleh dari kolom jumlah pada tabel sedangkan kolom prioritas diperoleh dari kolom prioritas pada tabel rasio konsistensi. Dari tabel tersebut diperoleh nilai-nilai sebagai berikut: Jumlah (Jumlahan dari nilai-nilai hasil): 111.72.

$$
\begin{aligned}
& \lambda \text { maks }=\frac{12.36+12.36+12.16+12.42+12.69+12.72+11.06+13.06+12.90+12.83+11.39}{11} \\
& \lambda \text { maks }=\frac{111.72}{11}=10.16 \\
& C I=\frac{(\lambda m a k s-n)}{(n-1)}=\frac{10.16-11}{11-1}=-0,084 \\
& I R=1,51 \\
& C R=\frac{C I}{I R}=\frac{-0,084}{1,51}=-0,0056
\end{aligned}
$$

Oleh karena CR < 0.1, maka rasio konsistensi dari perhitungan tersebut bisa diterima.

Setelah menghitung kriteria, langkah selanjutnya menghitung nilai dari setiap subkriteria, cara perhitungannya bisa disamakan dengan cara perhitungan kriteria diatas. Perhitungan subkriteria KOT.

1. Membuat matriks perbandingan berpasangan

Tabel 6. Matriks Perbandingan Berpasangaan KOT

\begin{tabular}{|l|l|l|l|l|}
\hline & Yatim\&piatu & Yatim & Piatu & Lengkap \\
\hline Yatim\&piatu & 1 & 3 & 5 & 7 \\
\hline Yatim & 0.33 & 1 & 2 & 3 \\
\hline Piatu & 0.2 & 0.5 & 1 & 2 \\
\hline Lengkap & 0.14 & 0.33 & 0.5 & 1 \\
\hline Jumlah & $\mathbf{1 . 6 7}$ & $\mathbf{4 . 8 3}$ & $\mathbf{8 . 5}$ & $\mathbf{1 3}$ \\
\hline
\end{tabular}


Citec Journal, Vol. 4, No. 1, November 2016 - Januari 2017

2. Membuat matriks nilai kriteria

Tabel 7. Matriks Nilai Kerja KOT

\begin{tabular}{|l|l|l|l|l|l|l|}
\hline & Yatim\&piatu & Yatim & Piatu & Lengkap & Jumlah & Prioritas \\
\hline Yatim\&piatu & 0.60 & 0.62 & 0.59 & 0.54 & $\mathbf{2 . 3 5}$ & $\mathbf{0 . 5 9}$ \\
\hline Yatim & 0.20 & 0.21 & 0.24 & 0.23 & $\mathbf{0 . 8 7}$ & $\mathbf{0 . 2 2}$ \\
\hline Piatu & 0.12 & 0.10 & 0.12 & 0.15 & $\mathbf{0 . 4 9}$ & $\mathbf{0 . 1 2}$ \\
\hline Lengkap & 0.08 & 0.07 & 0.06 & 0.08 & $\mathbf{0 . 2 9}$ & $\mathbf{0 . 0 7}$ \\
\hline
\end{tabular}

Total nilai prioritas digunakan untuk mendapatkan bobot kriteria sehingga menjadi:

Tabel 8. Bobot Kriteria KOT

\begin{tabular}{|l|l|}
\hline KOT & Prioritas \\
\hline Yatim\&piatu & $\mathbf{0 . 5 9}$ \\
\hline Yatim & $\mathbf{0 . 2 2}$ \\
\hline Piatu & $\mathbf{0 . 1 2}$ \\
\hline Lengkap & $\mathbf{0 . 0 7}$ \\
\hline
\end{tabular}

3. Membuat matriks penjumlahan tiap baris

Tabel 9. Matriks Penjumlahan Tiap Baris TF

\begin{tabular}{|l|l|l|l|l|l|}
\hline & Yatim\&piatu & Yatim & Piatu & Lengkap & Jumlah \\
\hline Yatim\&piatu & 0.59 & 0.65 & 0.62 & 0.50 & $\mathbf{2 . 3 6}$ \\
\hline Yatim & 0.19 & 0.22 & 0.25 & 0.22 & $\mathbf{0 . 8 7}$ \\
\hline Piatu & 0.12 & 0.11 & 0.12 & 0.14 & $\mathbf{0 . 4 9}$ \\
\hline Lengkap & 0.08 & 0.07 & 0.06 & 0.07 & $\mathbf{0 . 2 9}$ \\
\hline
\end{tabular}

4. Membuat rasio konsistensi

Tabel 10. Rasio Konsistensi TF

\begin{tabular}{|l|l|l|l|}
\hline & Jumlah & Prioritas & Hasil \\
\hline Yatim\&piatu & 2.36 & 0.59 & 2.95 \\
\hline Yatim & 0.87 & 0.22 & 1.09 \\
\hline Piatu & 0.49 & 0.12 & 0.62 \\
\hline Lengkap & 0.29 & 0.07 & 0.36 \\
\hline Jumlah & $\mathbf{5 . 0 2}$ \\
\hline
\end{tabular}

$$
\begin{aligned}
& \lambda \text { maks }=\frac{2,95+1,09+00,62+0,36}{4}=\frac{5,02}{4}=1,25 \\
& C I=\frac{(\lambda \text { maks }-\mathrm{n})}{(n-1)}=\frac{1,25-4}{4-1}=-0,92 \\
& C R=\frac{C I}{I R}=\frac{-0,92}{0,90}=-1,02
\end{aligned}
$$

Oleh karena CR < 0.1, maka rasio konsistensi dari perhitungan tersebut bisa diterima. Untuk perhitungan subkriteria yang lainnya bisa dilakukan perhitungan seperti KOT. 


\subsubsection{Menghitung Hasil}

Dimana proses perhitungan kriteria dan subkriteria harus mengasilkan sebuah prioritas hasil sesuai seperti pada langkah-langkah perhitungan kriteria diatas, kemudian dituangkan dalam matriks hasil. Dari setiap perhitungan diatas, maka menghasilkan bobot dari seluruh subkriteria. Dimana bobot ini akan menjadi nilai dalam melakukan perhitungan untuk menentukan ranking bagi penerima Bantuan Siswa Misin (BSM), seperti pada Tabel 11.

Tabel 11. Matriks Hasil

\begin{tabular}{|c|c|c|c|c|c|c|c|c|c|c|}
\hline KKPS & KOT & POT & TOA & JR & KP & $\mathbf{K H}$ & NS & PA & PNA & PL \\
\hline 0.16 & 0.16 & 0.13 & 0.11 & 0.10 & 0.09 & 0.06 & 0.05 & 0.05 & 0.04 & 0.04 \\
\hline $\begin{array}{l}\text { Memiliki } \\
\text { KPS }\end{array}$ & $\begin{array}{l}\text { Yatim } \\
\text { \&Piatu }\end{array}$ & $>=3 \mathrm{jt}$ & $>5$ anak & $\begin{array}{l}>=10 \\
\mathrm{~km}\end{array}$ & $\begin{array}{l}\text { Sangat } \\
\text { Baik }\end{array}$ & $75-84 \%$ & $>=91$ & $\begin{array}{l}\text { Tingkat } \\
\text { Nasional }\end{array}$ & $\begin{array}{l}\text { Tingkat } \\
\text { Nasional }\end{array}$ & $\begin{array}{l}\text { Kelainan } \\
\text { fisik \& } \\
\text { korban } \\
\text { musibah }\end{array}$ \\
\hline 0.9 & 0.59 & 0.59 & 0.63 & 0.42 & 0.42 & 0.63 & 0.42 & 0.42 & 0.42 & 0.59 \\
\hline $\begin{array}{l}\text { Tidak } \\
\text { Memiliki } \\
\text { KPS }\end{array}$ & Yatim & $1.5-3 \mathrm{jt}$ & $\begin{array}{l}3-5 \\
\text { anak }\end{array}$ & $7-9 \mathrm{~km}$ & Baik & $\begin{array}{l}85-90 \\
\%\end{array}$ & $81-90$ & $\begin{array}{l}\text { Tingkat } \\
\text { Provinsi }\end{array}$ & $\begin{array}{l}\text { Tingkat } \\
\text { Provinsi }\end{array}$ & $\begin{array}{l}\text { Kelainan } \\
\text { fisik }\end{array}$ \\
\hline \multirow[t]{7}{*}{0.1} & 0.22 & 0.22 & 0.26 & 0.26 & 0.26 & 0.26 & 0.26 & 0.26 & 0.26 & 0.22 \\
\hline & Piatu & $\begin{array}{l}<=1.5 \\
\text { jt }\end{array}$ & $\begin{array}{l}1-2 \\
\text { anak }\end{array}$ & $4-6 \mathrm{~km}$ & Cukup & $\begin{array}{l}91-100 \\
\%\end{array}$ & $71-80$ & $\begin{array}{l}\text { Tingkat } \\
\text { Kabupaten }\end{array}$ & $\begin{array}{l}\text { Tingkat } \\
\text { Kabupaten }\end{array}$ & $\begin{array}{l}\text { korban } \\
\text { musibah }\end{array}$ \\
\hline & 0.12 & 0.12 & 0.11 & 0.16 & 0.16 & 0.11 & 0.16 & 0.16 & 0.16 & 0.12 \\
\hline & Lenkap & $\begin{array}{l}\text { Tidak } \\
\text { Ada }\end{array}$ & & $1-3 \mathrm{~km}$ & Kurang & & $61-70$ & $\begin{array}{l}\text { Tingkat } \\
\text { Sekolah }\end{array}$ & $\begin{array}{l}\text { Tingkat } \\
\text { Sekolah }\end{array}$ & Tidak ada \\
\hline & 0.07 & 0.07 & & 0.10 & 0.10 & & 0.10 & 0.10 & 0.10 & 0.07 \\
\hline & & & & $<1 \mathrm{~km}$ & $\begin{array}{l}\text { Sangat } \\
\text { kurang }\end{array}$ & & $<=60$ & $\begin{array}{l}\text { Tidak } \\
\text { Ada }\end{array}$ & Tidak Ada & \\
\hline & & & & 0.06 & 0.06 & & 0.06 & 0.06 & 0.06 & \\
\hline
\end{tabular}

Selanjutnya memasukkan data nilai dari semua siswa yang akan dihitung. Jika diberikan data nilai dari 3 orang siswa seperti yang terlihat dalam tabel matriks hasil, maka hasil akhirnya akan nampak dalam Tabel 12.

Tabel 12. Nilai Penerima Bantuan Siswa Miskin

\begin{tabular}{|l|l|l|l|l|l|l|l|l|l|l|l|}
\hline NAMA & KKPS & KOT & POT & TOA & JR & KP & KH & NS & PA & PNA & PL \\
\hline SISWA A & $\begin{array}{l}\text { Tidak } \\
\text { memliki } \\
\text { KPS }\end{array}$ & Yatim & $\begin{array}{l}\text { Rp. } \\
3.100 .000\end{array}$ & 2 & $5 \mathrm{~km}$ & Baik & $81 \%$ & 80 & $\begin{array}{l}\text { tingkat } \\
\text { provinsi }\end{array}$ & $\begin{array}{l}\text { Tidak } \\
\text { ada }\end{array}$ & $\begin{array}{l}\text { Tidak } \\
\text { ada }\end{array}$ \\
\hline SISWA B & $\begin{array}{l}\text { Kemiliki } \\
\text { KPS }\end{array}$ & Piatu & $\begin{array}{l}\text { Rp. } \\
800.000\end{array}$ & 4 & $7 \mathrm{~km}$ & Baik & $88 \%$ & 80 & $\begin{array}{l}\text { Tingkat } \\
\text { sekolah }\end{array}$ & $\begin{array}{l}\text { Tidak } \\
\text { ada }\end{array}$ & $\begin{array}{l}\text { Kelainan } \\
\text { fisik }\end{array}$ \\
\hline SISWA C & $\begin{array}{l}\text { Memiliki } \\
\text { KPS }\end{array}$ & Lengkap & $\begin{array}{l}\text { Rp. } \\
1.000 .000\end{array}$ & 3 & $2 \mathrm{~km}$ & Cukup & $77 \%$ & 92 & Tidak ada & $\begin{array}{l}\text { Tingkat } \\
\text { sekolah }\end{array}$ & $\begin{array}{l}\text { Korban } \\
\text { musibah }\end{array}$ \\
\hline
\end{tabular}

Dari hasil perhitungan data siswa, diperoleh nilai total masing-masing siswa yang akan digunakan sebagai dasar untuk mendapatkan laporan siswa yang akan direkomendasikan sebagai siswa yang menerima Bantuan Siswa Miskin. seperti terlihat pada Tabel 13. 
Citec Journal, Vol. 4, No. 1, November 2016 - Januari 2017

Tabel 13. Perhitungan Nilai Hasil Akhir

\begin{tabular}{|l|l|l|l|l|l|l|l|l|l|l|l|l|}
\hline NAMA & KKPS & KOT & POT & TOA & JR & KP & KH & NS & PA & PNA & PL & Jumlah \\
\hline SISWA A & 0.1 & 0.22 & 0.59 & 0.11 & 0.16 & 0.26 & 0.11 & 0.16 & 0.26 & 0.06 & 0.07 & $\mathbf{2 . 1}$ \\
\hline SISWA B & 0.9 & 0.12 & 0.12 & 0.26 & 0.26 & 0.26 & 0.26 & 0.16 & 0.1 & 0.06 & 0.22 & $\mathbf{2 . 7 2}$ \\
\hline SISWA C & 0.9 & 0.07 & 0.12 & 0.26 & 0.11 & 0.16 & 0.11 & 0.42 & 0.06 & 0.1 & 0.12 & $\mathbf{2 . 4 3}$ \\
\hline
\end{tabular}

Sehingga dari hasil perhitungan diatas, menghasilkan rating untuk calon siswa penerima Bantuan Siswa Miskin dari nilai tertinggi ke nilai terendah. seperti terlihat pada Tabel 14.

Tabel 14. Rating Keputusan

\begin{tabular}{|l|l|l|l|l|l|l|l|l|l|l|l|l|}
\hline NAMA & KKPS & KOT & POT & TOA & JR & KP & KH & NS & PA & PNA & PL & Jumlah \\
\hline SISWA B & 0.9 & 0.12 & 0.12 & 0.26 & 0.26 & 0.26 & 0.11 & 0.16 & 0.1 & 0.06 & 0.22 & $\mathbf{2 . 7 2}$ \\
\hline SISWA C & 0.9 & 0.07 & 0.12 & 0.26 & 0.1 & 0.16 & 0.11 & 0.42 & 0.06 & 0.06 & 0.12 & $\mathbf{2 . 4 3}$ \\
\hline SISWA A & 0.1 & 0.22 & 0.59 & 0.11 & 0.16 & 0.26 & 0.26 & 0.16 & 0.26 & 0.06 & 0.07 & $\mathbf{2 . 1}$ \\
\hline
\end{tabular}

\subsection{Perancangan Sistem}

\subsubsection{Use case Diagram}

Use case adalah metode berbasis teks untuk menggambarkan dan mendokumentasikan proses yang kompleks [8]. Use case sangat berguna ketika situasi yang dianalisis sangat kompleks. Berikut adalah use case diagram dalam sistem pendukung keputusan calon penerima Bantuan Siswa Miskin (BSM) seperti pada Gambar 3.

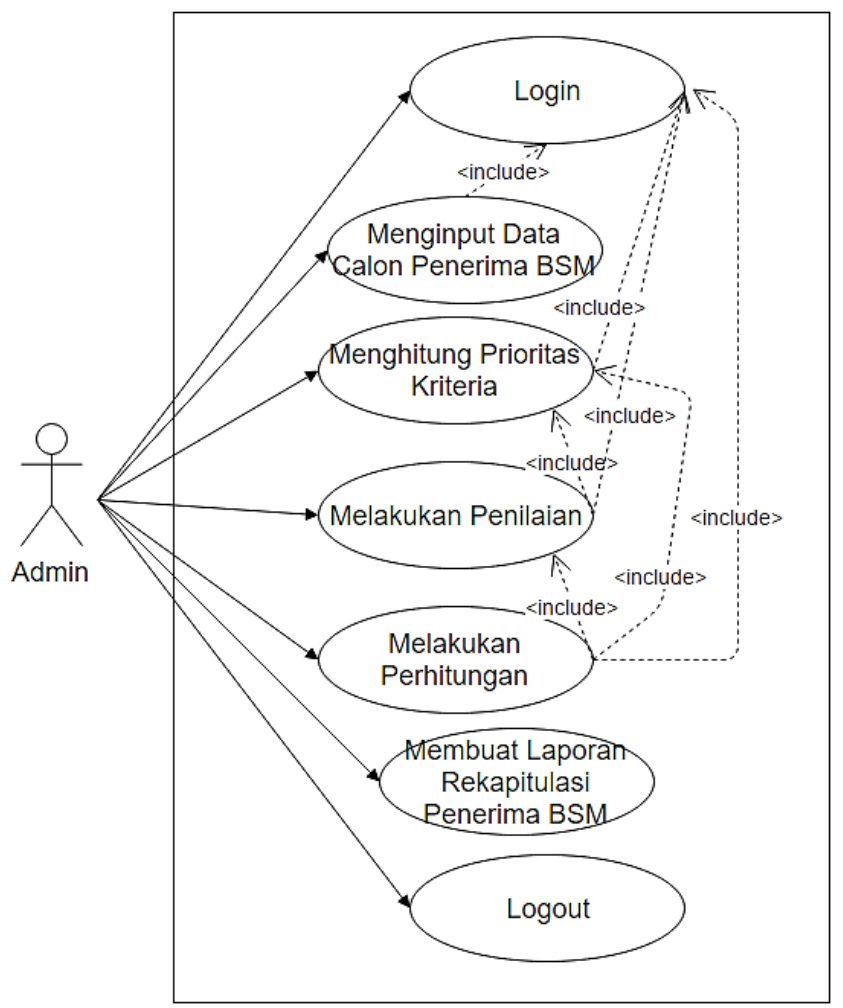

Gambar 3. Use Case Diagram 


\subsubsection{Perancangan Basis Data}

Rancangan basis data merupakan proses untuk menentukan isi dan pengaturan yang dibutuhkan untuk mendukung berbagai perancangan sistem, adapun detai ERD ini bisa dilihat pada Gambar 4.

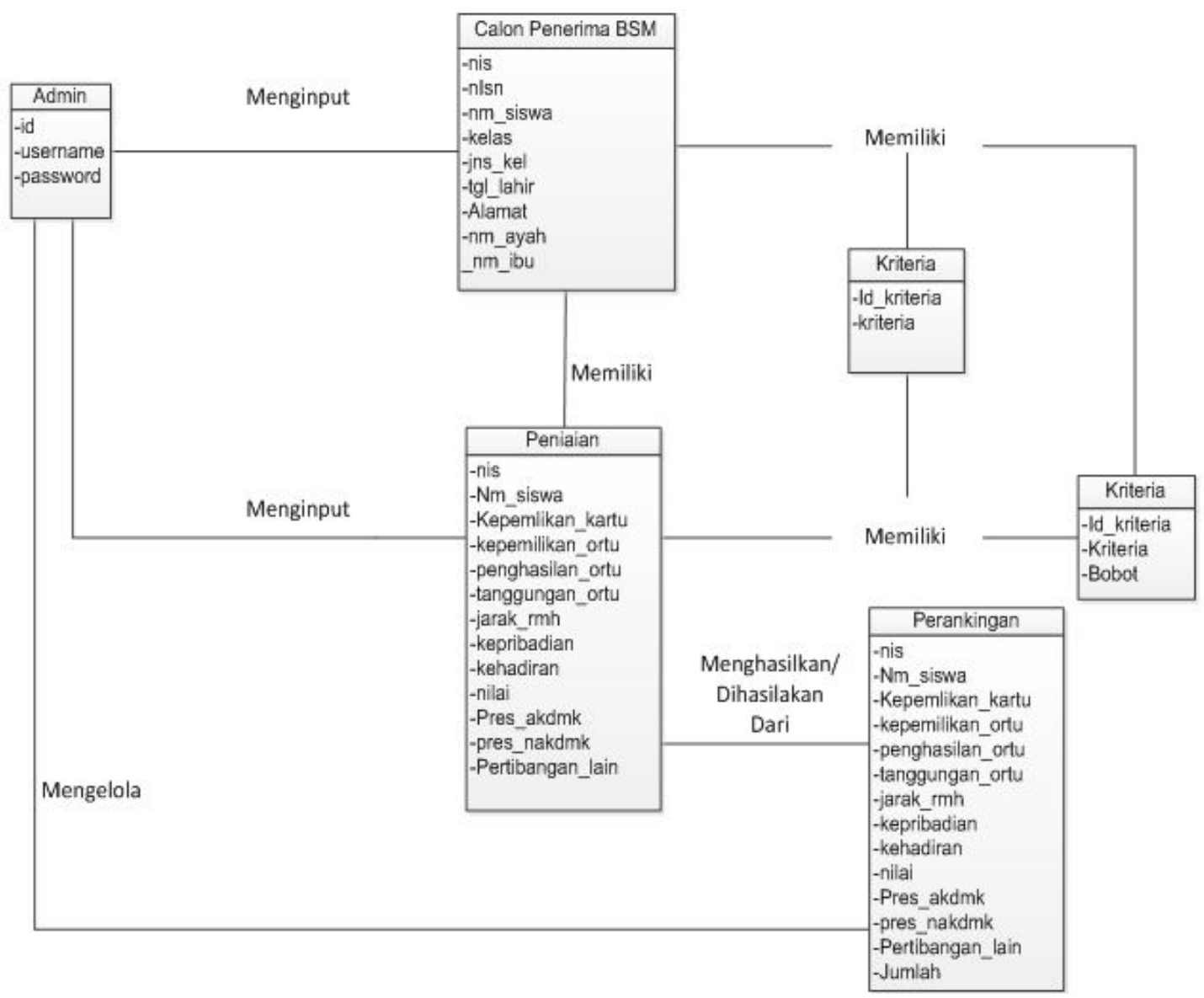

Gambar 4. Entity Relationship Diagram

\subsubsection{Implementasi Sistem}

Implementasi merupakan langkah yang dilakukan setelah perancangan SPK Pemilihan Calon Penerima Bantuan Siswa Miskin di SMP Negeri 4 Ciamis. Program aplikasi SPK ini terdiri dari beberapa halaman.

Untuk menjalankan aplikasi SPK ini, admin harus Login terlebih dahulu dalam sebuah form dengan mengisi username dan password, seperti yang terlihat pada Gambar 5. Jika benar, maka akan masuk ke form Menu Utama.

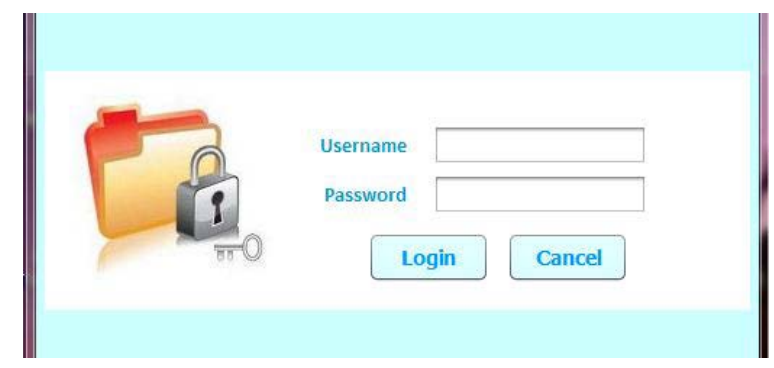

Gambar 5. Form Login 
Citec Journal, Vol. 4, No. 1, November 2016 - Januari 2017

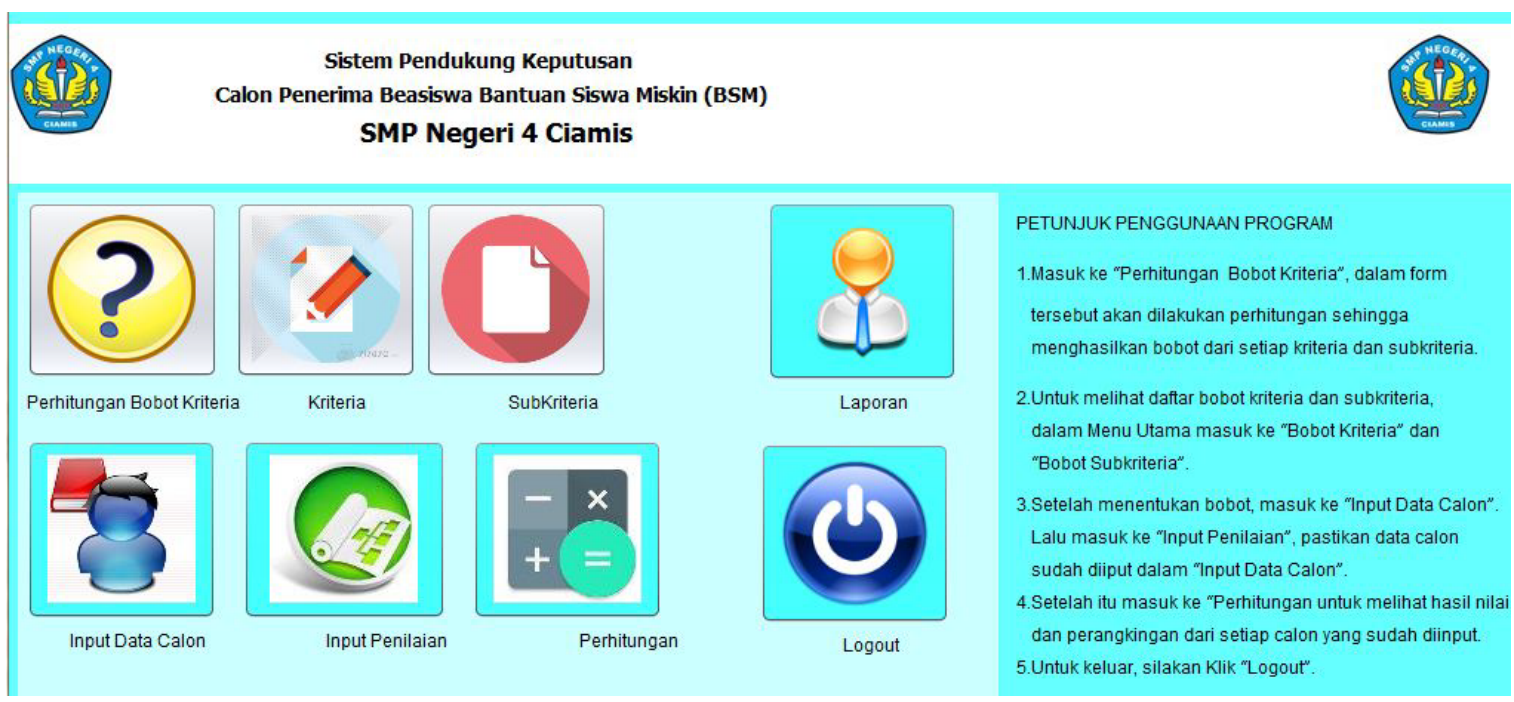

Gambar 6. Form Menu Utama

Setelah login berhasil maka akan muncul menu utama yang menyediakan menu perhitungan bobot kriteria, kriteria, subkriteria, input data calon, input penilaian, perhitungan, laporan dan logout . Disertakan juga petunjuk penggunaan program seperti yang terlihat pada Gambar 6.

Kemudian pilih menu prioritas, di dalam menu ini terdapat beberapa sub pilihan yang digunakan untuk menghitung bobot atau prioritas dari setiap kriteria dan subkriteria, seperti pada Gambar 7.

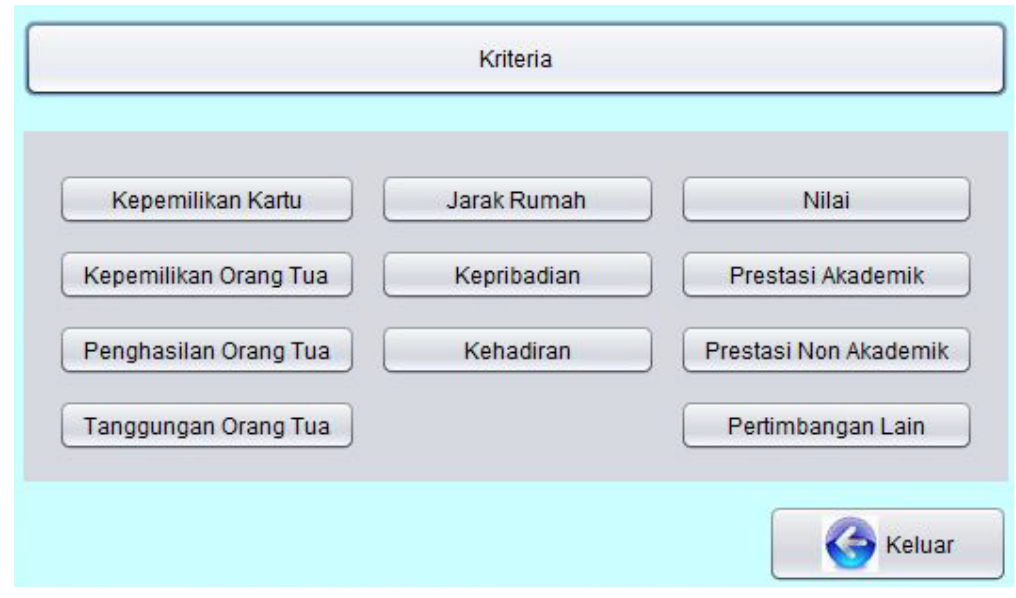

Gambar 7. Form Indikator

Setelah memilih salah satu menu sub kriteria, maka akan tampil form kriteria. Form ini digunakan untuk menghitung bobot atau prioritas dari setiap kriteria umum. Juga menampilan uji konsistensi yang menghasilkan nilai Rasio Konsistensi (CR), seperti yang ada pada Gambar 8. 


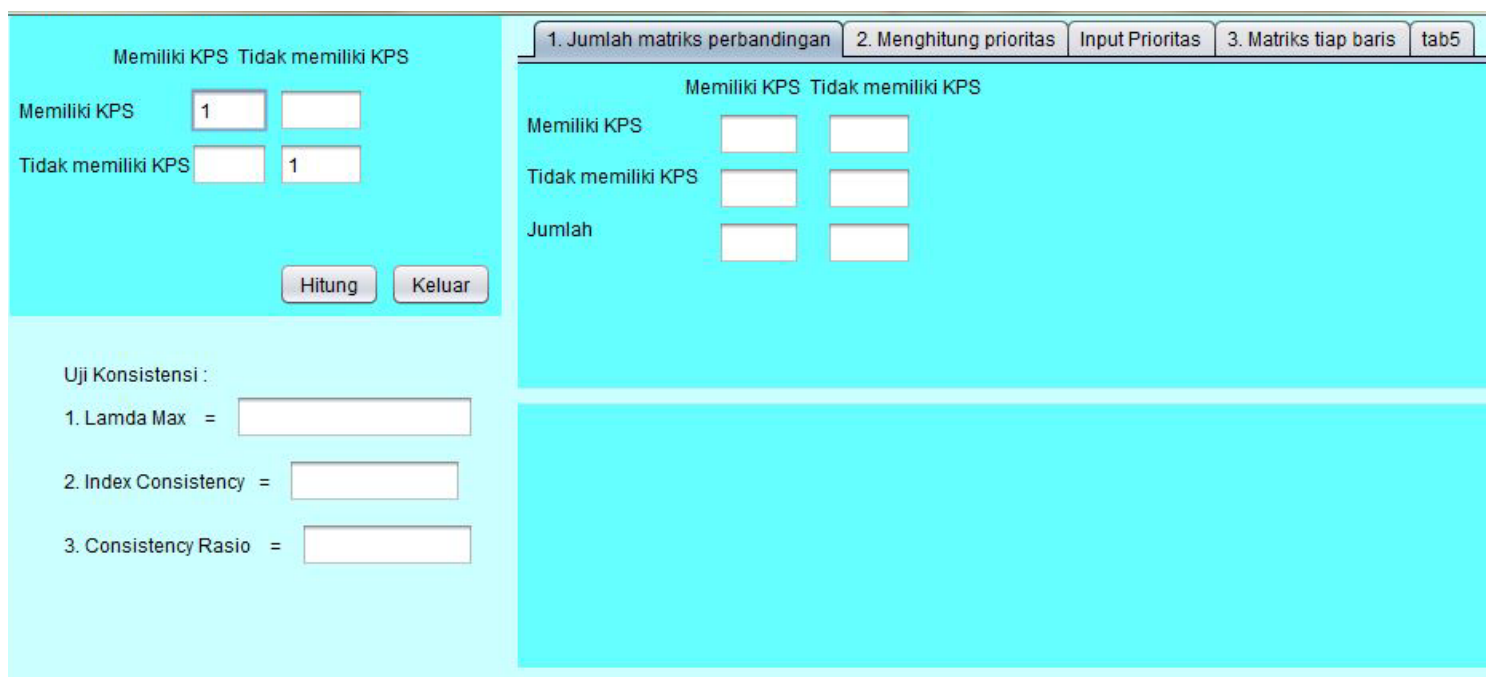

\section{Gambar 8. Form Kriteria KKPS}

Setelah semua form indikator berhasil dihitung dan disimpan, kemudian inputkan data siswa penerima bantuan siswa miskin, seperti yang terlihat pada Gambar 9.

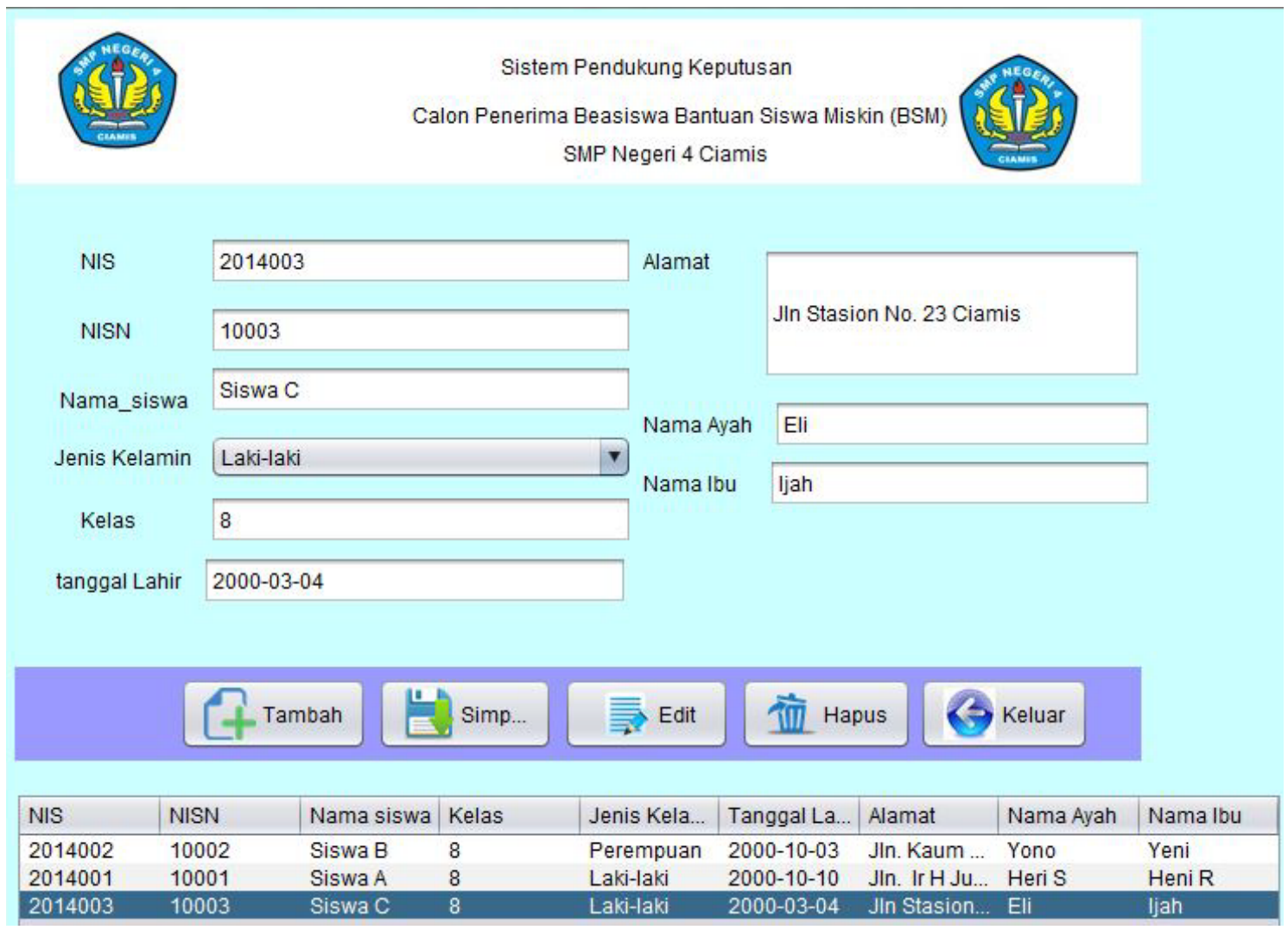

Gambar 9. Form Input Data Siswa

Jika data sudah diinputkan, langkah selanjutnya menginputkan data nilai siswa sesuai nama siswa yang sudah disimpan dalam form input siswa. Form ini harus diisi dengan nilai-nilai kriteria. Tampilan terlihat pada gambar 10. 
Citec Journal, Vol. 4, No. 1, November 2016 - Januari 2017

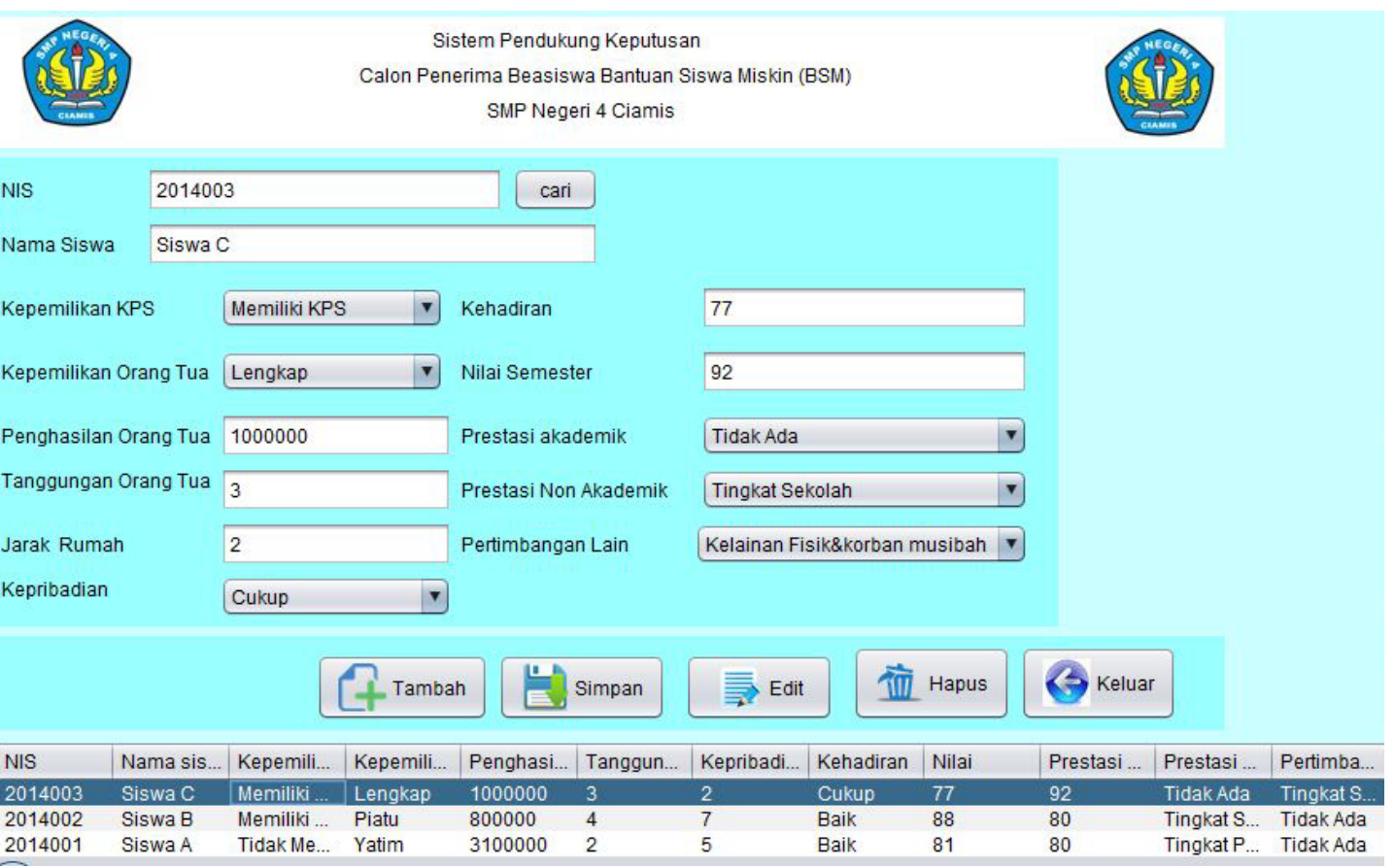

Gambar 10. Form Input Nilai Siswa

Setelah semua data diinputkan dan di simpan, maka akan dilanjutkan ke proses perhitungan, dan hasil perhitungan dari form keputusan ini akan langsung diurutkan dari yang terbesar sampai yang terkecil, hasil bisa dilihat pada Gambar 11.

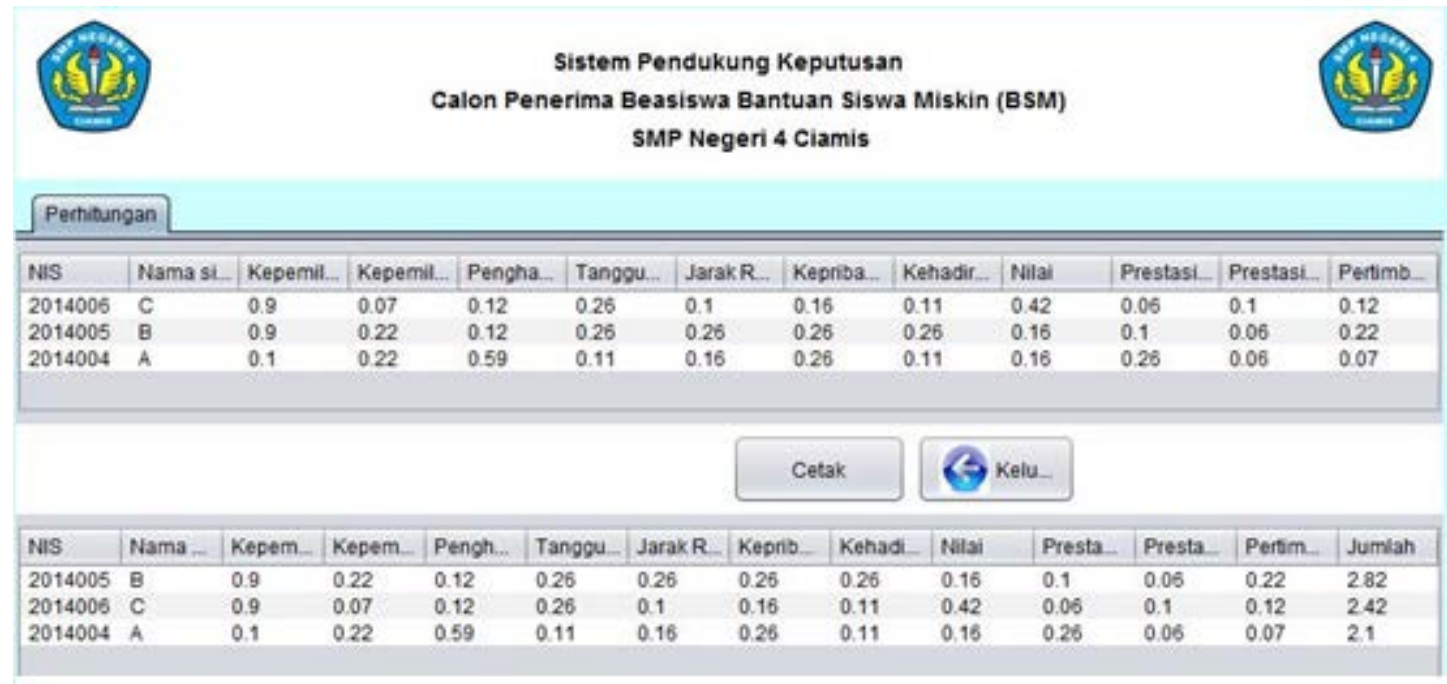

\section{Gambar 11. Form Keputusan AHP}

\section{KESIMPULAN}

Setelah melakukan penelitian, pembahasan, dan pengujian yang telah dilakukan di SMP Negeri 4 Ciamis, tentang sistem pendukung keputusan pemilihan penerima bantuan siswa miskin dapat diambil beberapa kesimpulan sebagai berikut:

1. Perhitungan Indikator yang digunakan untuk penilaian pemilihan calon penerima beasiswa, bisa dihitung meggunakan program Sistem Pendukung Keputusan Pemilihan Calon penerima beasiswa Bantuan Siswa Miskin (BSM), yaitu data calon penerima BSM diproses 
menggunakan penghitungan Analytical Hierarchy Process, sehingga menghasilkan sebuah nilai kelayakan. Dari nilai tersebut bisa dilihat siapa saja yang berhak menadi calon penerima BSM. Siswa yang berhak menerima beasiswa BSM, diambil dari nilai prioritas yang lebih tinggi.

2. Program Sistem Pendukung Keputusan Pemilihan Calon penerima beasiswa Bantuan Siswa Miskin (BSM), dapat membantu Tim Seleksi dalam menghitung kelayakan calon penerima beasiswa Bantuan Siswa Miskin (BSM) sehingga dalam proses perhitungan dan pelaporannya lebih cepat.

\section{SARAN}

Saran yang dapat diajukan untuk pengembangan dan perbaikan Sistem Pendukung Keputusan untuk menentukan penerima BSM yaitu:

1. Dilakukan penambahan kriteria-kriteria yang relevan untuk meningkatkan akurasi dari proses penyeleksian.

2. Sistem dilengkapi dengan Sistem Informasi Geografis (SIG) untuk mengetahui pola sehingga dapat dipetakan berdasarkan wilayah siswa penerima BSM dan juga asal sekolahnya.

\section{DAFTAR PUSTAKA}

[1] Mufizar, T., Rohpandi, D., Wine, 2014. Sistem Pendukung Keputusan Penerimaan Mahasiswa Baru Program Beasiswa D3 TKJ Dengan Metode SAW (Simple Additive Weighting). Konferensi Nasional Sistem Informasi, pp.1066-1070.

[2] Vaidya, O. S., Kumar, S., 2006, Analytic hierarchy process: An overview of applications, European Journal of Operational Research, Vol 169, No. 1, hal. 1-29.

[3] Ariyadi, B. D., 2013, Sistem Pendukung Keputusan Seleksi Penerima Beasiswa pada SMA 1 Boja Dengan Menggunakan Metode Analytic Hierarchy Process (AHP), Skripsi, Fakultas Ilmu Komputer, Universitas Dian Nuswantoro, Semarang.

[4] Saelindri, P. S., 2014, Sistem Pendukung Keputusan Untuk Menentukan Kelayakan Penerimaan Bantuan Siswa Miskin (BSM) Dengan Menggunakan Metode TOPSIS, Skripsi, Fakultas Ilmu Komputer, Universitas dian Nuswantoro, Semarang

[5] Rinaldhi, G. E., 2014. Penerapan Metode Simple Additive Weighting (saw) untuk Sistem Pendukung Keputusan Penerimaan Beasiswa Bantuan Siswa Miskin pada Sekolah Menengah Atas Negeri 1 Subah Kabupaten Batang, Skripsi, Fakultas Ilmu Komputer, Universitas Dian Nuswantoro, Semarang.

[6] Mufizar, T. Nuraen, T. Andrianto, D., 2015, Sistem Pendukung Keputusan untuk Menyeleksi Calon Penerima Bantuan Siswa Miskin (BSM) di MTs Negeri Ciamis Menggunakan Metode Simple Additive Weighing (SAW), Seminar Nasional Informatika (SNIf) 2015, Medan, 22 Agustus 2015.

[7] Kusrini, 2007, Konsep dan Aplikasi Sistem Pendukung Keputusan, Andi, Yogyakarta.

[8] Rosa, A.S., Shalahuddin, M., 2013, Rekayasa Perangkat Lunak Terstruktur dan Berorientasi Objek. Informatika, Bandung. 